\title{
Racial Steering: The Real Estate Broker and Title VIII
}

Eight years ago, the National Advisory Commission on Civil Disorders warned that America was rapidly moving toward two separate societies, one white and one black. ${ }^{1}$ Residential segregation, documented by the Commission, continues to be nearly universal. ${ }^{2}$ Segregated housing patterns cannot be entirely explained by the economic disparities between black and white buyers ${ }^{3}$ or by individual choice.

1. National Advisory Commission on Civil Disorders, Report 225 (1968).

2. Id. at 118-20. See Hearings on Equal Educational Opportunity Before the Senate Select Comm. on Equal Educational Opportunity, 9lst Cong., 2d Sess., pt. v, at 2727-32 (1970) (statement of Karl E. Taueber) [hereinafter cited as 1970 Hearings], reaffirming the findings of K. Taueber \& A. Taueber, Negroes in Crties: Residential Segregution and Neighborhood Change (1965).

Between 1970 and 1974, black residents in inner city areas increased by 800,000 (to $22 \%$ of the total population of those areas), while net white emigration from the central cities was 4.3 million. Bureau of the Census, Current Population Reports, Social and Economic Characteristics of the Metropolitan and Nonmetropolitan Population: 1974 AND 1970, at 4, 8 (Ser. P-23, No. 55, 1975). See geverally Long, How the Racial Composition of Cities Changes, 51 LaNb Econ. 258 (1975). Although black population in the suburbs increased by more than $1 / 2$ million, blacks remained only five percent of the total suburban population in 1974 (the same percentage as in 1960 and 1970). BUREA of the Census, Current Population Reports, The Social and Economic Status of the Black Population in the United States 1974, Table 5 at 14, Table 6 at 15 (Ser. P.23, No. 54, 1975). For a detailed description of minority migration and urban residential segregation, see United States Commission on Civil Rights, Twenty Years After Brown: Equal Opportunity in Housing 119-36 (1975) [hereinafter cited as Equal. OpPORTUNITY IN HOUSING].

The growing black population in the suburbs does not necessarily indicate an increase in the number of integrated communities. See Connolly, Black Movement into the Suburbs: Suburbs Doubling Their Black Populations During the 1960s, 9 URB. AFF. Q. 91, 97-98 (1973) (black expansion "fundamentally attributable to the physical expansion of inner-city ghettos into contiguous areas" as well as to transformation of predominantly black suburban areas into ghettos); Farley, The Changing Distribution of Negroes Within Metropolitan Areas: The Emergence of Black Suburbs, 75 AM. J. Soc. $512,526-27$ (1970) (while black emigration slows the growth of black population in the cities, it does not alter the fact of metropolitan racial segregation).

3. See J. Kain \& J. Quigley, Housing Markets and Racial Discrimination 57-58 (1975); National Committee Against Discrimination in Housing (NCDH), Jobs and Housing: A Study of Employment and Housing Opportunities for Racial Minorities in the Suburban Areas of the New York Metropolitan Region 41 (Interim Report, March 1970); Cottingham, Black Income and Metropolitan Residential Dispersion, 10 UrB. AfF. Q. 273, 292 (1975); Hermalin \& Farley, The Potential for Residential Integration in Cities and Suburbs: Implications for the Busing Controversy, 38 AM. Soc. REv. 595, 601 (1973).

4. See J. KaIN \& J. QuigleY, supra note 3, at 58-61; 1970 Hearings, supra note 2, at 2730 (statement of Karl E. Taueber). 
Such housing patterns are, to a significant extent, the result of the practices of the real estate brokerage industry.

The real estate broker has traditionally performed a "gatekeeping" function, directing white buyers to predominantly white areas and minority buyers to minority or interracial areas. ${ }^{6}$ This practice is called racial steering. ${ }^{7}$ While certain forms of steering have been held to violate Title VIII of the Civil Rights Act of $1968,{ }^{8}$ courts have yet to articulate fully the reasoning behind those holdings or to consider the entire range of steering practices which may come within the statutory prohibition. This Note analyzes racial steering practices and concludes that virtually all are unlawful under Title VIII. It argues that Title VIII's most far-reaching prohibition against steering is its "colorblind" standard, which forbids real estate brokers from treating customers differently on the basis of race.

\section{The Practice of Racial Steering}

Racial steering is a generic term for a variety of longstanding and ubiquitous practices by which a real estate broker directs buyers toward or away from particular houses or neighborhoods according to the buyer's race. ${ }^{9}$ These practices may be divided into two broad

5. United States Commission on Civil Rights, Equal Opportunity in Suburbia 16 (1974). See NCDH, supta note 3, at 80; Nattonal Neighbors, Racial Stefring: The Dual Housing Market and Multiracial Neighborhoods 3 (1973). But cf. E. Mills, URBAN ECONOMIICs 168 (1972) ("[T]o blame housing segregation on realtors and mortgage lenders is like blaming bad news on the journalist.")

6. See S. Palmer, The Role of the Real Estate Agent in the Structuring of Residential Areas: A Study in Social Control 56.57 (1955) (unpublished Ph.D. thesis in Yale University Library); Barresi, The Role of the Real Estate Agent in Residential Location, 1 Soc. Focus, Summer 1968, at 59, 60 .

7. For definitions of racial steering, see NAtionsl. Association of Realtors, Realtors Guide to Practice Equal Opportunity in Housing 23 (1973) [hereinafter cited as RealTors Guide]; National Neighbors, supra note 5, at 10; Zuch v. Hussey, 394 F. Supp. 1028, 1017-48 (E.D. Mich. 1975).

This Note deals only with racial steering. However, the analysis applies as well to Title VIII liability of brokers for steering based on sex, religion, or ethnicity because discrimination on these grounds is also prohibited by Title VIII. See p. 813 infra. While references to ethnic and religious steering exist in the literature, e.g., S. Palmer, supra note 6 , at 110-13, 121-27, no suits have been brought challenging such practices.

8. Zuch v. Hussey, 394 F. Supp. 1028, 1047 (E.D. Mich. 1975); United States v. Robbins, P.H EQ. OPP. Hous. If 13,655 (S.D. Fla. 1974).

This Note focuses on the legality of steering under Title VIII of the Civil Rights Act of 1968, 42 U.S.C. $\$ \$ 3601-31$ (Supp. IV 1974). For a discussion of liability for steering under 42 U.S.C. $\$ 1982$ (1970), see note 23 infra.

9. For discussions of the nature and extent of racial steering, see Nationat NeighBors, stupra note 5, at 20-24; H. Openshaw, Race and Residence: AN ANALYsis of Property Valuts in Transitionat. AReas, Atlanta, Georgia, 1960-1971, at 56 (Georgia State University, School of Business Administration, Monograph No. 53, 1973); United States Commission on Civil Rights, Home Ownership for Lower-INCome Families: A Report on the Racial and Ethnic Impact of the Section 235 Program 60-61 (1971); Saltman, 
classes of conduct: (l) advising customers to purchase homes in particular neighborhoods on the basis of race; ${ }^{10}$ and (2) failing, on the basis of race, to show, or to inform buyers of, homes that meet their specifications. ${ }^{11}$

Brokers steer for a variety of reasons. Sellers may instruct brokers

Implementing Open Housing Laws Through Social Action, 11 J. App. Behsv. Sc1. 39, $43-45$ (1975); Hearings on the Federal Government's Role in the Achievement of Equal Opportunity in Housing Before the Subcomm. on Civil Rights Oversight of the Housc Comm. on the Judiciary, 92d Cong., 2d Sess. 49 (1971-i2).

The nationwide scope of the steering problem is suggested by the number of jurisdictions in which actions complaining of steering practices have been filed. See Fair Hous. Council of Bergen County v. Eastern Bergen County Multiple Listing Serv., Civ. No. 76-418 (D.N.J., filed Mar. 8, 1976); Center for Advocacy, Research and Planning, Inc. v. Eaton, Civ. No. 75-117 (D. Conn., filed June 12, 1975); Zuch v. Hussey, 394 F. Supp. 1028 (E.D. Mich. 1975); Heights Community Congress v. Rosenblatt Realty, Inc., P-H EQ. OPP. Hous. \ 13,702 (N.D. Ohio 1975) ; Village of Park Forest v. Fairfax Realty, P-H EQ. OpP. Hous. I 13,699 (N.D. Ill. 1975); TOPIC v. Circle Realty Co., 377 F. Supp. 111 (C.D. Cal. 1974), aff'd in part and rev'd in part, Civ. No. 74-2147 (9th Cir., Mar. 23, 1976); United States v. Saroff, 377 F. Supp. 352 (E.D. Tenn. 1974), aff'd without opinion, 516 F.2d 902 (6th Cir. 1975); United States v. Henshaw Bros., Inc., 401 F. Supp. 399 (E.D. Va. 1974); United States v. Robbins, P-H EQ. OpP. Hous. đ 13,655 (S.D. Fla. 1974); United States v. Real Estate One, Inc., Civ. No. 39743 (E.D. Mich., filed Mar. 21, 1973).

The Department of Justice and defendant real estate agencies have also entered numerous consent decrees. United States v. Corbin, Civ. No. AC-75-160 (W.D.N.C. Mar. 9, 1976); United States v. Ashcraft, Civ. No. S-75-57C (E.D. Mo. Aug. 28, 1975); United States v. Stan Weber \& Assocs., Civ. No. $73-512$ (E.D. La. Jan. 17, 1975); United States v. Salling, Civ. No. 74-752-LTL (C.D. Cal. Oct. 30, 1974); United States v. Barrows \& Wallace Co., Civ. No. 74-143 (D. Conn. July 25, 1974); United States v. Chess Realty Co., Civ. No. 73-2205 (E.D. Pa. May 29, 1974); United States v. Mabry, Civ. No. 73-J-150-R (S.D. Miss. Mar. 11, 1974); United States v. Lackey, Civ. No. 73-648-Civ-T-K (M.D. Fla. Jan. 2, 1974); United States v. Grempler Realty, P-H EQ. OPP. Hous. I 18,002 (D. Md. 1972).

10. Such advice may take the form of disparaging interracial neighborhoods to white customers, while telling black customers that they would not be "comfortable" living in predominantly white neighborhoods. See Findings of Fact at 15, United States v. Real Estate One, Inc., Civ. No. 39743 (E.D. Mich., entered Apr. 26, 1976); Zuch v. Hussey, 394 F. Supp. 1028, 1041 (E.D. Mich. 1975); Barresi, supra note 6, at 69. Brokers may also discourage buyers from looking for homes in certain neighborhoods by explicitly mentioning the neighborhood's racial composition. See Zuch v. Hussey, supra at 1037, 1039. Racial information may also be communicated to the buyer through code words or phrases-for example, by characterizing neighborhoods as "busted," "changing," "deteriorating," or "not nice." See, e.g., id. at 1036.

11. For examples of practices by which brokers attempt to deny black buyers the opportunity to purchase homes in white areas, see Findings of Fact at 10-15, United States v. Real Estate One, Inc., Civ. No. 39743 (E.D. Mich., entered Apr. 26, 1976); United States v. Robbins, P-H EQ. OPP. Hous. If 13,655 (S.D. Fla. 1974); United States v. Northside Realty Assocs:, Inc., P-H EQ. Opp. Hous. đI 13,552 (N.D. Ga. 1971); R. Helper, RaciaL Policies and Practices of Real Estate Brokers 42-43 (1969); Bogen \& Falcon, The Use of Racial Statistics in Fair Housing Cases, 34 MD. L. REv. 59, $62-63$ (1974); Barresi, supra note 6 , at 69 ; S. Palmer, supra note 6 , at $133-42$.

Steering may also take the more subtle form of offering for the buyer's consideration only homes in neighborhoods composed predominantly of persons of the buyer's race. . See National Neighbors, supra note 5, at 20 (results of Cleveland, Ohio study); pp. 817-18 infra. This conduct, often based on a broker's desire to please his customers, is part of the broker's customary practice of matching buyers with neighborhoods in which the broker believes they would feel comfortable. For a description of this customary practice, see Barresi, supra note 6, at 62-63; S. Palmer, supra note 6 , at $12-16,65 \cdot 66,180$. 
not to show their homes to members of a particular race. ${ }^{12}$ Where the broker steers on his own initiative, he tends to justify the practice by relying on traditional industry values. Until 1950, the Code of Ethics of the real estate brokerage industry ${ }^{13}$ encouraged racial steering. ${ }^{14}$ The National Association of Realtors (NAR) and its constituent local boards have in the past been vocal opponents of fair housing legislation. ${ }^{15}$

While the industry has recently adopted an official policy of nondiscrimination, ${ }^{16}$ this change in industry norm is not likely to eliminate steering. One sociologist has identified a pervasive "broker ideology" which fosters the practice of racial steering. ${ }^{17}$ Brokers generally assume

12. One New Haven realtor cited pressure by white sellers to maintain segregated neighborhoods as a major factor in racial steering. Interview with Albert Poirier, New Haven, Conn. (Nov. 19, 1974) (notes on file with Yale Law Journal).

13. The major trade organization in the real estate industry is the National Association of Realtors (NAR) (called the National Association of Real Estate Boards (NAREB) until 1973). NAR represents over 1500 local boards and 84,000 individual members. Hearings on S. $135 S$, S. 2114, S. 2280 Before the Subcomm. on Housing and Urban Affairs of the Senate Comm. on Banking and Currency, 90th Cong, Ist Sess. 337 (1967) [hereinafter cited as Hearings on S. 135S]. Black brokers, originally excluded from NAREB, formed the National Association of Real Estate Brokers in 1948. See Brown, Access to Housing: The Role of the Real Estate Industry, 48 Econ. GEOGRAPHY 66, 70 (1972).

14. Until 1950, Article 34 of NAREB's Code of Ethics stated:

A realtor should never be instrumental in introducing into a neighborhood a character of property or occupancy, members of any race or nationality, or any individual whose presence would clearly be detrimental to property values in that neighborhood.

R. HeLPER, supra note 11, at 201 (emphasis added). See Equal Opportunity in Housing, supra note 2, at 4. Although reference to race was deleted from the Code, apparently for public relations reasons, the change was one of appearance and not effect. See J. DENTON, ApARTHEID-AMERICAN STYLe 48 (1967); R. HeLPER, supra note 11, at 201; Hearings on $S$. $135 s$, stupra note 13 , at 201 . Helper found that the official policies of national and local broker organizations contribute directly to the beliefs and practices of the broker. $R$. HELPER, supra note 11 , at 261.

15. See J. Denton, supra note 14, at 2-19; Brown, supra note 13, at 71-72; Hearings on S. 1358 , supra note 13, at 337 (statement of Alan L. Emlen, chairman, Realtors Washington Comm. of NAREB). For the position of the black broker organization (the National Association of Real Estate Brokers), see id. at 185 (statement of Q.V. Williamson strongly supporting open housing legislation).

After the passage of Title VIII, NAREB interpreted the Act narrowly. It informed its members that the law did not require that a black customer requesting general information about available homes be told of houses the broker knew to be available in white neighborhoods. Grayson \& Wedel, Open Housing: How to Get Around the Law, 158 NEW Republic, June 22, 1968, at 15 (citing NAREB memorandum).

16. The NAR recommends that all members implement its code for Equal opportunity "so that a unified, positive policy may prevail among [member brokers] and so that we may set a good example in this sensitive field." REALTors Guide, supra note 7, at 3. The Code for Equal Opportunity essentially repeats the prohibitions of Title VIII and includes specific applications of the general principle that brokers "have the responsibility to offer equal service to all clients and prospects without regard to race." Id. at 5 .

17. A perceptive analysis of the broker's attitudes and values is developed in $R$. Hecper, supra note 11, at 143-54. The author identifies five core beliefs of what she terms the "exclusion ideology" shared by many brokers: (1) most whites do not want black neighbors; (2) property values decline as black residents enter white neighborhoods; 
that white home owners and home buyers desire segregated communities. ${ }^{18}$ Accordingly, a broker may steer white buyers toward white neighborhoods in the belief that he is satisfying their preferences, and steer black buyers away from such areas in order to preserve the values and standards of the white areas in which he operates. ${ }^{19}$ If the broker assumes that buyers prefer to live with persons of their own race, he may not view his practices as discriminatory or their segregative effects as pernicious. Rather, both the practices and effects may be seen as consistent with the segregative tendencies of the society at large.

Steering may also be good business. It pays well when used in a "blockbusting" strategy, where a broker, in order to frighten white owners into selling their homes, represents that blacks are purchasing homes in the neighborhood. ${ }^{20}$ The broker then guides black buyers toward, and white buyers away from, the transitional neighborhood. In predominantly white neighborhoods that are not undergoing racial change, the broker may steer to avoid the loss of patronage that might result if he showed or sold homes to blacks. ${ }^{21}$ Finally, racial steering is attractive to brokers on grounds of simple business efficiency. The quickest and surest sales can be made by satisfying buyer preferences, which brokers assume to be for neighborhoods inhabited by members of the buyer's own race. ${ }^{22}$

\section{Statutory Liability ${ }^{23}$}

\section{A. Section 3604(a): Making Housing Available}

Section 3604(a) of Title VIII of the Civil Rights Act of 1968 provides that it shall be unlawful

(3) integrated neighborhoods eventually become resegregated; (4) whites are hurt financially and socially by sales to blacks in white areas; and (5) selling to blacks in white areas is an unethical business practice.

18. Id. at 140 .

19. See id. at 117-20. Such conduct is not limited to racial steering. Brokers may also seek to preserve communities on the basis of class, ethnicity, or religion. See Barresi, supra note 6, at 60; S. Palmer, supra note 6, at 12.

20. Blockbusting is prohibited by 42 U.S.C. $\$ 3604(e)(1970)$. For a general discussion of the methods of blockbusting, see Note, Blockbusting, 59 GEo. L.J. 170 (1970); Note, Blockbusting: $A$ Novel Statutory Approach to an Increasingly Serious Problem, 7 CoLUM. J. Law \& Soc. Prob. 538 (1971).

21. See R. Her.per, supra note 11 , at 94,140 . Cf. S. Palmer, supra note 6 , at 66 (brokers fear consequences of introducing members of different social groups into homogeneous neighborhoods). But cf. Barresi, supra note 6, at 64 (brokers surveyed indicate little outside pressure and believe their views are consistent with, but not determined by, community values).

22. National Neighbors, supra note 5 , at 12.

23. This section discusses broker liability for steering under Title VIII. However, racial steering may also violate 42 U.S.C. $\$ 1982(1970)$, which provides: "All citizens of the United States shall have the same right ... as is enjoyed by white citizens ... to 
[t]o refuse to sell or rent after the making of a bona fide offer, or to refuse to negotiate for the sale or rental of, or otherwise make unavailable or deny, a dwelling to any person because of race, color, religion, sex, or national origin. ${ }^{24}$

While the phrase "otherwise make unavailable" has been read broadly by the courts, ${ }^{25}$ it has not yet been construed with any precision. The

... purchase ... real and personal property." Several steering cases have alleged claims uncler the section. Johnson v. Jerry Pals Real Estate, 485 F.2d 528 (7th Cir. 1973) (broker who falsely told black buyer that no homes were available in white areas violated both Title VIII and \$1982; court did not state reasoning for finding \$ 1982 violation); Heights Community Congress v. Rosenblatt Realty, Inc., P-H EQ. OPP. Hous. $\{13,702$ (N.D. Ohio $1975)$ (standing allowed under Title VIII; $\$ 1982$ issue not reached); Village of Park Forest v. Fairfax, P-H EQ. Opp. Hous. If 13,699 (N.D. Ill. 1975) (standing found under Title VIII and denied under $\$$ 1982); TOPIC v. Circle Realty, 377 F. Supp. 111 (C.D. Cal. 1974), aff'd in part and rev'd in part, Civ. No. 74-2147, slip op. at 2 n.4 (9th Cir. Mar. 23, 1976) (standing denied under $\$ 1982$ ).

Enacted as part of the 1866 Civil Rights Act, $\$ 1982$ lay dormant until the Supreme Court's holding in Jones v. Alfred H. Mayer Co., 392 U.S. 409 (1968), that $\S 1982$ prohibits private as well as public discrimination in the sale or rental of housing. The Court was careful to distinguish the section from the recently-enacted Title VIII, stating that "\$ 1982 is not a comprehensive open housing law." Id. at 413. The Court contrasted the two statutes in language which seemed to leave open the possibility that $\$ 1982$ could be applied to brokerage services: "[\$ 1982] does not deal specifically with discrimination in the provision of services or facilities in connection with the sale or rental of a dwelling." Id. at 413 (emphasis added; footnote omitted). Whether $\$ 1982$ in fact applies to brokerage services depends upon the meaning of the section's guarantee of "the same right" to purchase property. The phrase clearly prohibits owners from refusing to sell their homes to a willing buyer on the basis of the buyer's race. See Jones v. Alfred $H$. Mayer Co., supra. It also reaches brokers who aid owners seeking to sell only to persons of a particular race. See Ford $r$. Wisconsin Real Estate Examination Bd., 48 Wis. 2d 91, 179 N.W.2d 786 (1970); see also Haythe v. Decker Realty Co., 468 F.2d 336 (7th Cir. 1972) (\$1982 prohibits racial discrimination in real estate transactions by sellers and brokers; but no violation found).

A more difficult case arises when the broker steers on his own initiative. In this situation, unlike that in which the owner refuses to sell, the purchase is not impossible. See pp. 813-14 infra. However, it could be argued that the broker may so impair the buyer's ability to find and purchase available housing that the buyer is effectively denied the right to purchase the property. It could also be argued that $\S 1982$ 's guarantee of the "same right" to purchase property prohibits any limitation, based on the buyer's race, of the opportunity to purchase housing. Cf. Clark v. Universal Builders, Inc., $501 \mathrm{~F} .2 \mathrm{~d}$ 324 (7th Cir:), cert. denied, 419 U.S. 1070 (1974) ("the same right" to purchase property includes ability of buyers to purchase similar homes in black and white neighborhoods at similar prices and on similar terms and conditions). But cf. Love v. DeCarlo Homes, Inc., 482 F.2d 613 (5th Cir.), cert. denied, 414 U.S. 1115 (1973) (finding no liability under $\$ 1982$ on facts similar to those in Clark).

For other arguments that $\$ 1982$ applies to steering, see Note, Housing and Section 19S2: The Advisability of Extending the Statutory Mandate Beyond Acts of Traditional Discrimination, 1975 Duke L.J. 781, 799-800 (1975) (steering by sellers of real estate); cf. Morris \& Powe, Constitutional and Statulory Rights to Open Housing, 44 WASH. L. REv. 1,83 (1968) ("Although section 1982 does not explicitly cover discriminatory terms and conditions or discriminatory misrepresentations of non-availability, the section would bc practically nullified if it were not construed to prohibit these practices.")

24. 42 U.S.C. $\$ 360 t$ (a) (Supp. IV 1974) (emphasis added).

25. See Laufman v. Oakley Bldg. \& Loan Co., 408 F. Supp. 489, 493 (S.D. Ohio 1976); United States v. Youritan Constr. Co., 370 F. Supp. 643, 648 (N.D. Cal. 1973), modified on other grounds, 509 F.2d 623 (9th Cir. 1975) (language "appears to be as broad as Con- 
phrase must be interpreted in its statutory context and with reference to the more specifically defined terms it accompanies. ${ }^{26}$ Hence, any practice is illegal under the last clause of $\S 3604$ (a) if it makes housing unavailable in the same manner as a refusal to sell or negotiate. When a broker refuses to negotiate, he impedes, but does not prevent, the buyer's purchase of a dwelling. Since the buyer can, seek the services of another broker or negotiate directly with the seller, a refusal to negotiate simply raises an obstacle between the buyer and available homes he might be interested in purchasing. Reading the subsection as limited to acts that make purchase impossible would immunize real estate brokers from liability under $\S 3604$ (a). If this analysis is applied to the last clause of the subsection, the phrase "otherwise make unavailable" should be construed to prohibit conduct that impedes or obstructs a willing buyer from purchasing, or considering the purchase of, an available home that meets his specifications. ${ }^{27}$

At least one court has held that broker advice that discourages white buyers from purchasing in black areas violates $\S 3604(a) \cdot{ }^{28}$ It is

gress could have made it"). However, a 1966 version of the Fair Housing Act, which failed to pass the Senate, used even broader language. H.R. 14765, 89th Cong., 2d Sess. $\$ 403$ (a)(7), 112 CoNg. REc. 22622 (1966): "[It is unlawful] [t]o engage in any act or practice, the purpose of which is to limit or restrict the availability of housing to any person or group of persons because of race ...." Senator Dirksen called this provision "the world with a fence around it." Id.

26. Ejusdem generis is an accepted principle of statutory construction. See 82 C.J.S. Statutes $\$ 332(\mathrm{~b})$ (1953).

27. See United States v. Long, P.H EQ. OPP. Hous. โ 13,631, at 14,090 (D.S.C. 1974) (Section 3604(a) "reaches every practice which has the effect of making housing more difficult to obtain on account of race.")

A broker cannot impede the purchase of housing if the buyer has no intention of making a purchase. Consequently, it is difficult to see how "testers"-persons who pose as purchasers in order to monitor broker compliance with fair housing legislation-can have housing made unavailable to them. But see Zuch v. Hussey, 394 F. Supp. 1028 (E.D. Mich. 1975) (housing made unavailable to testers in violation of $\S 3604(\mathrm{a})$ ). For an argument that testers may sue under $\$ 3604(\mathrm{~b})$, see note 48 infra.

The first clause of the $\$ 3604$ (a) provides that it is unlawful to refuse to sell or rent "after the making of a bona fide offer." $P$. 813 supra. The bona fide offer require. ment applies only to the prohibition against refusals to sell or rent. See United States v. Youritan Constr. Co., 370 F. Supp. 643, 650 (N.D. Cal. 1973), modified on other grounds, 509 F.2d 623 (9th Cir. 1975); 114 CoNG. Rec. 5515 (1968) (sponsor of amendment adding bona fide offer requirement stated that "the latter part of paragraph (a) is not conditioned upon a bona fide offer, because the amendment as offered concludes with the word 'or' rather than 'and' '). Interpreting the subsection to require a bona fide interest in purchasing before housing can be made unavailable does not read the bona fide offer requirement into the remainder of the subsection. Indeed, persons with a bona fide interest in purchasing may be unable to make a bona fide offer precisely because housing has been made unavailable to them. Therefore the limitation of the bona fide offer requirement to refusals to sell or rent is not inconsistent with the view that testers without a bona fide interest in purchasing a home do not have a cause of action under the remainder of the subsection.

28. Zuch v. Hussey, 394 F. Supp. 1028 (E.D. Mich. 1975); cf. United States v. Long, P-H EQ. OPp. Hous. โ 13,631 (D.S.C. 1974) (owner-developer's policy of discouraging blacks from living in white areas held to violate $\$ 3604(a))$. 
hard to see how such conduct, while undoubtedly a steering practice, makes housing unavailable within the meaning of the subsection. Even though discouragement or encouragement by a broker may influence a buyer's choice, the broker neither refuses to show homes nor creates an obstacle to a buyer's desired purchase. The buyer is free to accept or reject the broker's advice. As long as the broker makes clear that he is willing to show the customer all available housing that meets the buyer's specifications, he does not make housing unavailable to a buyer who merely follows his advice.

If brokers may provide advice on the basis of race without violating $\$ 3604(a)$, it would seem to follow that they may also lawfully provide factual information. Where the broker conveys accurate information without an explicit or implicit value judgment, ${ }^{29}$ it is difficult to

Zuch is the only case to discuss at length Title VIII liability for steering. The court found that brokers were attempting to accelerate the racial transition of a neighborhood in Detroit by combining steering with blockbusting. (For a discussion of the use of steering as part of a blockbusting strategy, see p. 812 supra.) Faced with evidence of bad faith manipulation of buyers and sellers, the court held that brokers illegally "made housing unavailable" by suggesting to white buyers that they not live in transitional neighborhoods. The court stated:

Unlawful steering or channeling of a prospective buyer is the use of a word or phrase or action by a real estate broker or salesperson which is intended to influence the choice of a prospective property buyer on a racial basis. ... Where choice influencing factors such as race are not eliminated, freedom of choice in the purchase of real estate becomes a fantasy. . . . It is the freedom of choice for the purchaser which the Fair Housing Act protects....

Accordingly, any action by a real estate agent which in any way impedes, delays, or discourages on a racial basis a prospective home buyer from purchasing housing is unlawful. ...

... [W] Wen a real estate agent actively undertakes an effort to influence the choice of a prospective home buyer on a racial basis ... the agent ... discourages the prospective home buyer from purchasing a home in a particular area.

391 F. Supp. at 1047, 1048 (citations omitted). The court did not explain how influencing the choice of a prospective buyer "makes housing unavailable" within the terms of $\S 3601(a)$. However, the court clearly held that "warnings" by brokers about the racial composition of an area which discourage white buyers from purchasing in that area violate the subsection.

For a consent decree prohibiting this form of racial steering, see United States v. Lackey, Civ. No. 73-648-Civ-T-K, at 16 (M.D. Fla. Jan. 2, 1974), which states that no information with respect to the racial composition of a particular area

shall be used to encourage any prospect to live in a neighborhood predominantly occupied by persons of his own race, and no prospect shall be warned or advised: (a) that he will not or may not be welcome in an area because of racial opposition in the neighborhood; or (b) that he should avoid purchasing or renting a home in a neighborhood because of the racial composition of the area.

29. Analytically, the difference between advice and information is clear enough: advice attempts to influence the buyer's choice by changing or molding his preferences, while provision of information merely helps the buyer to make his own choice according to his existing preferences. In practice, however, the line between the two may be more difficult to draw. The manner in which information is transmitted to the buyer-with a raised eyebrow or a particular tone of voice-may transform it into advice. Consider, for example, such statements as: "Yes, there are homes available in that neighborhood, but it is $50 \%$ black, you know." 
term such conduct steering and harder still to characterize it as making housing unavailable. And if brokers may volunteer racial information, a fortiori they may respond to buyer questions concerning the racial composition of the neighborhood. ${ }^{30}$

Although $\$ 3604$ (a) does not appear to prohibit a broker from advising buyers where to purchase ${ }^{31}$ or from informing them of the racial

30. Cf. United States v. Saroff, 377 F. Supp. 352, 361 (E.D. Tenn. 1974), aff'd without opinion, 516 F.2d 902 (6th Cir. 1975) ("agent's good faith response to an inquiry made by the homeowner regarding the race of a prospective buyer of his home is not per se violative [of $\$ 3604$ (e)] where . . . the agent's answer is not couched in such a fashion as to prey upon the fears of the homeowner"). But cf. Zuch v. Hussey, 394 F. Supp. 1028, 1051 n.11 (E.D. Mich. 1975) ("defendants clearly went beyond any reasonable discussion of race which might be lawfully permissible" under $\$ 3604$ (a); but court reserved judgment on question whether race can ever be discussed in real estate transaction).

In its consent decrees the Justice Department has allowed brokers to answer questions by buyers about the racial composition of a neighborhood. See, e.g., Consent Decree at 5, United States v. Mabry, Civ. No. 73-J-150-R (S.D. Miss. Mar. 11, 1974) ("Information with respect to the racial composition of a particular area . . . shall only be made available in response to a specific question concerning such racial composition.") Similarly, NAR advises its members that "[a]bsent unusual circumstances, questions [requesting racial information] . . . may be answered factually with a disclaimer of any intention to show or offer homes on a racial basis." Resliors GuIDE, supra note 7, at 22.

One commentator has suggested that if a legislature decides that a buyer has no right to choose a home on the basis of race, it could forbid a broker from answering questions about changes in the racial composition of a neighborhood. An Anti-Blockbusting Ordinance, 7 HARv. J. LEGIs. $402,412(1970)$. But such a rule would deprive the buyer of the broker's special knowledge and experience. See Note, supra note 23, at 800 . A ban on answering questions would also raise serious First Amendment issues. See note 31 infra; cf. United States v. Mintzes, 304 F. Supp. 1305, 1312 (D. Md. 1969) (First Amendment problem raised if $\$ 3604$ (e)'s prohibition against blockbusting interpreted to reach honest answers to questions by homeowners).

31. Other subsections of $\$ 3604$ may reach such conduct. If the broker encourages members of one race to live in a particular neighborhood and discourages members of another race as to the same neighborhood, he would be liable under $\S 3604$ (b). See p. 819 infra.

In addition, one court has held that encouraging buyers to choose a home on the basis of the racial composition of the neighborhood is prohibited by 42 U.S.C. $\$ 3604$ (c) (Supp. IV 1974), which makes it unlawful

[t]o make, print, or publish, or cause to be made, printed, or published any notice, statement, or advertisement, with respect to the sale or rental of a dwelling that indicates any preference, limitation, or discrimination based on race, color, religion, sex, or national origin, or an intention to make any such preference, limitation, or discrimination.

(Emphasis added). United States v. Long, P-H EQ. Opp. Hous. I 13.631, at 14,091 (D.S.C. 1974) ("Defendant's admitted policy of attempting to talk blacks out of living in white buildings and areas, and of encouraging them to live in black or transitional areas or complexes violates 42 U.S.C. $\$ 3604(\mathrm{c}) . ")$

While the subsection is most clearly aimed at discriminatory advertising, sce, e.g., United States v. Hunter, 459 F.2d 205 (4th Cir.), cert. denied, 409 U.S. 934 (1972), limiting the reach of the subsection solely to advertisements would render the word "statement" surplusage. Mayers v. Ridley, 465 F.2d 630, 633, 649 (D.C. Cir. 1972) (en banc) (Wright \&. Wilkey, J.J., respectively, concurring) (six judges agreeing that $\$ 360 t(\mathrm{c})$ prohibits the District of Columbia Recorder of Decds from recording restrictive covenants); see United States v. Hunter, supra at 210 ("each phrase in a statute must, if possible, be given effect"). Thus, the subsection could be interpreted to prohibit, in addition to advertisements, other statements indicating a racial preference in connection with the sale or 
composition of various neighborhoods, ${ }^{32}$ the subsection clearly bars practices that prevent buyers, on the basis of their race, from seeing homes that meet their specifications. Such practices may consist of affirmative misrepresentations as to the availability of a home ${ }^{33}$ or deliberate failures by the broker to show a buyer homes in which the buyer might reasonably be interested. ${ }^{34}$ Also illegal is more subtle conduct that does not evidence any overt refusal to show particular homes and that may stem from good faith as well as bad faith motives. For example, the broker may only show or suggest homes to buyers in neighborhoods composed predominantly of members of the buyer's race. This practice, which may be termed "matching steering," has never been held illegal and has only recently been challenged in

rental of a dwelling. See United States v. L \& H Land Corp., 407 F. Supp. 576, 580 (S.D. Fla. 1976) (statements by managing agent of apartment building that tenants could not entertain black guests violated $\S 3604(\mathrm{c})$ ). This construction is narrower than the one adopted by the court in Mayers $v$. Ridley, supra, where the person prohibited from acting was not himself engaged in the sale of a dwelling, but would clearly reach statements by brokers such as "the seller does not wish to sell to blacks." The subsection would also scem to prohibit statements of encouragement or discouragement based on race (such as advice to a white buyer not to purchase homes in black areas), because such statements indicate a preference that the area be reserved for buyers of a particular race.

This interpretation may raise First Amendment problems. The Supreme Court has recently held that the First Amendment does not permit the government to "com. pletely suppress the dissemination of concededly truthful information about entirely lawful activity," even though the information takes the form of commercial advertising. Virginia State Bd. of Pharmacy v. Virginia Citizens Consumer Council, Inc., 44 U.S.L.W. 4686, 4693 (U.S. May 24, 1976) (Virginia statute prohibiting pharmacists from advertising prescription drug prices violates the First Amendment). The court distinguished Funter on the ground that there the transaction proposed by the advertisement was illegal. Id. at 4693. The First Amendment may now limit the reach of $\S 3604(c)$ to indications of racial preference in a commercial context which promote or encourage acts otherwise illegal under the statute, such as making housing unavailable or discriminating in the provision of brokerage services. Subsection (c) then would add nothing to the prohibition on advice already contained in $\$ 3604(\mathrm{~b})$. See pp. 818-21 infra.

32. However, the broker would violate $\$ 3604(\mathrm{~b})$ if he provided different information to black and white buyers. See pp. 819-20 infra.

33. See United States v. Henshaw Bros., Inc., 401 F. Supp. 399, 401 (E.D. Va. 1974). Such misrepresentations are explicitly prohibited by 42 U.S.C. $\$ 3604$ (d) (Supp. IV 1974), which provides that it shall be unlawful " $[t]$ o represent to any person because of race, color, religion, sex, or national origin that any dwelling is not available for inspection, sale or rental when such dwelling is in fact so available."

34. See United States v. Henshaw Bros., Inc., 401 F. Supp. 399 (E.D. Va. 1974). The broker may similarly frustrate purchases by showing black buyers only those homes in white areas that do not meet their specifications (thereby making unavailable homes in white areas that do meet their specifications) or by failing to inform buyers of homes that become available after the initial meeting with the buyer, but before the buyer has purchased a home. For allegations of such conduct, see Complaint at 16, 17, Fair Hous. Council of Bergen County v. Eastern County Multiple Listing Serv., Inc., Civ. No. 76.418 (D.N.J., filed Mar. 8, 1976). Cf. United States v. Northside Realty Assocs., Inc., P-H EQ. OPP. Hous. If 13,552 (N.D. Ga. 1971), remanded for further proceedings, 474 F.2d 1164 (5th Cir. 1973) (white broker enjoined from referring black purchasers to black brokerage agencies). 
court. ${ }^{35}$ Matching steering is within the prohibition of $\$ 3604$ (a) because it eliminates an entire class of homes from a class of buyers on the basis of race. It effectively makes housing unavailable in the avoided neighborhoods, without the buyer being aware that those homes are on the market. The broker should be liable even if he does not intend to deny the buyer available housing. The subsection does not require a showing of intent; it refers only to prohibited acts. ${ }^{30}$

\section{B. Section 3604(b): Discriminatory Provision of Services and the Colorblind Standard}

Although courts and litigators have focused on $\S$ 3604(a) as a statutory prohibition of racial steering, $\S 3604(\mathrm{~b})$ appears to provide a broader ban. ${ }^{37}$ Section 3604 (b) provides that it shall be unlawful

$[t]$ o discriminate against any person in the terms, conditions, or privileges of sale or rental of a dwelling, or in the provision of services or facilities in connection therewith, because of race, color, religion, sex, or national origin. ${ }^{38}$

No court has construed the phrase "in the provision of services or facilities in connection therewith," nor is it explained in the legislative history of Title VIII. By interpreting the phrase to refer to services in connection with the sale of a dwelling, ${ }^{39}$ courts can reach

35. See Complaint at 16, Fair Housing Council of Bergen County v. Eastern Bergen County Multiple Listing Serv., Inc., Civ. No. 76-418 (D.N.J., filed Mar. 8, 1976); Complaint at 2, United States v. Real Estate One, Inc., Civ. No. 39743 (E.D. Mich., filed Mar. 21, 1973).

36. For cases holding that an intent to discriminate need not be demonstrated to establish a violation of Title VIII, see United States v. Pelzer Realty Co., 484 F.2d 438, 443 (5th Cir. 1973), cert. denied, 416 U.S. 396 (1974); United States v. Hughes Memorial Home, 396 F. Supp. 544, 548 (W.D. Va. 1975).

37. Two racial steering cases have alleged a cause of action under subsection (b), but have not been decided on the merits. TOPIC v. Circle Realty, Inc., Civ. No. 74-2147 (9th Cir. Mar. 23, 1976) (denying standing to fair housing group); Village of Park Forest v. Fairfax Realty, P-H EQ. OPP. Hous. đ 13,699 (N.D. Ill. 1975) (standing granted under Title VIII; issue of discrimination not reached). While the court in United States v. Saroff, 377 F. Supp. 352, 365 (E.D. Tenn. 1974), aff'd withoul opinion, 516 F.2d 902 (6th Cir. 1975), referred to an allegation under $\$ 3604(\mathrm{~b})$ and found no violation, the Justice Department's complaint made no mention of the subsection. Complaint at $4, i d$.

38. 42 U.S.C. $\$ 3604$ (b) (Supp. IV 1974) (emphasis added).

39. This interpretation is supported by Jones v. Alfred H. Mayer Co., 392 U.S. 409, 413 (1968). The Court contrasted $\$ 3604(\mathrm{~b})$ with 42 U.S.C. $\$ 1982$ (1970), which "does not deal specifically with discrimination in the provision of services or facilities in connection with the sale or rental of a dwelling" (footnote omitted). But see Sullivan v. Little Hunting Park, Inc., 396 U.S. 229, 247-48 (1969) (Harlan, J., dissenting), where Justice Harlan apparently interpreted this phrase in $\$ 3604(\mathrm{~b})$ to mean services and facilities connected with a dwelling. He cited the phrase to show that the Court could rely on Title VIII, and need not expand $\$ 1982$, to reach a refusal of a community park to allow a member to assign his membership to a black man to whom he leased his house. (Curiously, however, Harlan also quoted the statement from Jones cited above.)

The use of the terms "services" and "facilities" in other sections of Title VIII suggests that the phrase "services or facilities" in $\$ 3604$ (b) refers to those in connection with the 
the discriminatory provision of real estate brokerage services. ${ }^{40}$

Racial discrimination is defined as treating similarly situated persons differently on the basis of their race. ${ }^{41}$ Since racial steering consists of channeling buyers to different neighborhoods according to race, nearly all forms of racial steering are discriminatory and therefore prohibited by $\S 3604(\mathrm{~b}) .^{42}$ The subsection clearly covers blatant discrimination, where brokers intentionally hinder members of one race and help members of another race to enter particular neighborhoods. Furthermore, when a broker advises whites and blacks seeking similar housing to live in different neighborhoods, he discriminates in the provision of brokerage services (even if he does not make housing unavailable in violation of $\S 3604(a)$ ). Matching steering is also barred, because white and black customers, differing only in race, are shown separate classes of homes. While matching steering would not be established if a buyer did not see available homes because he chose the first home shown to him, a broker may not arrange the order in which he shows homes on the basis of the buyer's race.

Section 3604(b)'s prohibition against discriminatory provision of brokerage services requires that a real estate agent not differentiate between buyers on the basis of race. As such, it establishes a legal standard of "colorblindness." 43 While such a standard may not reach

sale or rental of a dwelling. See 42 U.S.C. $\$ 3603(b)(1)$ (1970) (exempting from Title VIIr any single-family house sold "without the use in any manner of the sales or rental facilities or the sales or rental services of any real estate broker, agent, or salesman"); id. $\$ 3606$ (Supp. IV 1974) (making it unlawful to deny any person access to any "service, organization, or facility relating to the business of selling or renting dwellings").

40. Although 42 U.S.C. $\S 3606$ (Supp. IV 1974) is entitled "Discrimination in the provision of brokerage services," it does not deal with provision of services by brokers to buyers, but rather with access to, or membership and participation in, brokerage organizations (such as multiple listing services).

41. See, e.g., Love v. DeCarlo Homes, Inc., 482 F.2d 613, 615 (5th Cir.), cert. denied, 414 U.S. 1115 (1973).

42. Section 3604 (b) expressly prohibits discrimination by brokers in the "terms, conditions, or privileges" of a sale. See United States v. Pelzer Realty Co., 484 F.2d 438 (5th Cir. 1973), cert. denied, 416 U.S. 936 (1974). Steering practices barred by $\$ 3604$ (b) are indirectly linked to this explicit prohibition. Steering helps to maintain separate housing markets for black and white buyers; and in markets restricted to black purchasers, houses are often sold at inflated prices and with less advantageous financing arrangements. For discussions of these "dual housing markets," see Clark v. Universal Builders, Inc., 501 F.2d 324, 328 (7th Cir.), cert. denied, 419 U.S. 1070 (1974); Love v. DeCarlo Homes, Inc., 482 F.2d 613, 615 (5th Cir.), cert. denied, 414 U.S. 1115 (1973); Contract Buyers League v. F \& F Inv., 300 F. Supp. 210 (N.D. Ill. 1969), aff'd on other grounds sub nom. Baker v. F \& F Inv., 420 F.2d 1191 (7th Cir.), cert. denied, 400 U.S. 821 (1970); J. KaIN \& J. QuicLEY, supra note 3, at 56-90.

43. As NAR advises its members: "[E]ach broker and agent should analyze his own procedures and ask: 'Are we doing that for everybody?' " REALTORs GuidE, supra note 7, at 23.

Senator Mondale stated during the Senate debate on Title VIII that "what this bill does is to make race irrelevant, which is the foundation of this country." 114 Cong. REC. 5643 (1968). A colorblind standard is implicit in consent decrees recently entered into by the Department of Justice and real estate agencies. See, e.g., United States v. Lackey, 
every conceivable form of racial steering, ${ }^{14}$ it sets a minimum standard of conduct by which the broker must abide in order to comply with Title VIII.

The colorblind standard sweeps more broadly than current Title VIII law and reaches steering practices other than those heretofore tested in court. ${ }^{45}$ It prevents the broker, at his own option, from selecting housing on the basis of race to show the customer. The broker must not assume racial preferences on the part of buyers. ${ }^{40} \mathrm{He}$ must be prepared to show all the homes within his operating area that meet the buyer's specifications, to provide the same information about particular neighborhoods to black and white buyers, ${ }^{47}$ and to show

Civ. No. 73-648, at 15 (M.D. Fla. Jan. 2, 1974), providing in part:

3. Whenever a prospect makes inquiry regarding a home or homes, the defendant shall make the prospect aware of the existence of all available homes of the same character and of the desired price range, without regard to the location of such homes, and will make available to the prospect an opportunity to ascertain the information with respect to all such homes.

4. The agents shall suggest and show homes and neighborhoods to all prospects without regard to race or color, and shall provide each black and each white prospect with full and accurate non-racial information regarding the desirability of all homes and neighborhoods suggested or shown by him.

5. No agent shall limit the homes shown or offered to be shown to any prospect or allocate an unreasonable proportion of such homes shown or offered to be shown, to areas in which a majority of the residents are of the prospect's own race, or in which there is a transition to such condition.

44. It is possible that brokers could treat black and white buyers alike and still steer them. For instance, a broker could tell every buyer he serves: "I advise you to live with members of your own race; these areas are predominantly black, and these white." There is no evidence that such conduct is common among brokers. Informational statements describing the racial composition of an area are also beyond the reach of the subsection if delivered in a similar fashion for white and black buyers.

45. The court in Zuch v. Hussey, 394 F. Supp. 1028, 1047 (E.D. Mich. 1975), defined "unlawful steering" as "the use of a word or phrase or action by a real estate broker or salesperson which is intended to influence the choice of a prospective property buyer on a racial basis." The Zuch rule is deficient both in including advice as unlawful steering under $\$ 3604(a)$, see pp. 814-15 supra, and more importantly in failing to include other forms of steering which are illegal under $\$ 3604(\mathrm{~b})$. The court appears to require $a$ showing of intent to influence buyer choice-an element that may either be lacking or very difficult to prove in a case of matching steering. Under the colorblind standard of $\$ 3604(b)$, different treatment of black and white buyers (or testers) would be a violation of Title VIII even absent a showing of intent. The standard would also impose liability for various broker practices which courts have loosely characterized as making housing unavailable. Hence, the court in United States v. Northside Realty Assocs., Inc., P.H EQ. OPP. Hous. If 13,552, at 13,721 (N.D. Ga. 1971), remanded for further proceedings, 474 F.2d 1164 (5th Cir. 1973), after finding that defendant had treated a black buyer "in a different manner than he would have treated white customers," could simply have found liability under $\S 3604(\mathrm{~b})$. Instead it held, with no analysis, that the conduct violated $\$ 3604(a)$.

46. The colorblind standard would not forbid the broker from telling buyers that he can act upon their specific instructions as to the type of neighborhoods they would like to see. But of. ReALTORS Guide, supra note 7, at 22 (NAR's advice to the broker that racial preferences not be honored).

47. In requiring the broker to provide similar information and advice to black and white buyers, $\$ 3604$ (b) regulates the broker's speech. The subsection presents no serious First Amendment problem, however, because it affects only speech which is an integral 
homes in a similar manner to all buyers. If adopted by the courts, the colorblind standard will encourage the use of "testers" to monitor broker compliance with Title VIII. A broker who practices steering could be recognized by the different treatment accorded black and white persons who pose as buyers and request similar homes. ${ }^{48}$

\section{Legislative History ${ }^{40}$}

The conclusion that racial steering violates Title VIII is consistent with the liberal interpretation ${ }^{50}$ accorded by courts in giving effect to

part of the brokerage services rendered to the buyer. The reasoning of one court in upholding $\$ 3604(e)$ 's blockbusting prohibition applies with equal force to subsection (b): "the statute is one regulating conduct, and ... any inhibiting effect it may have on speech is justified by the Government's interest in protecting its citizens from discriminatory housing practices and is not violative of the First Amendment." United States v. Bob Lawrence Realty, Inc., 313 F. Supp. 870, 872 (N.D. Ga. 1970), aff'd, 474 F.2d 115 (5th Cir. 1973); accord, United States v. Mitchell, 327 F. Supp. 476 (N.D. Ga. 1971). Cf. Cox v. Louisiana, 379 U.S. 559, 564 (1965) (upholding state statute prohibiting courthouse picketing as "a valid law dealing with conduct subject to regulation so as to vindicate important interests of society," and stating that "the fact that free speech is intermingled with such conduct does not bring with it constitutional protection"); United States v. Varani, 435 F.2d 758, 762 (6th Cir. 1970) (conviction for attempt to interfere with the administration of tax laws does not violate First Amendment: "speech is not protected when it is the very vehicle of a crime itself"). This conclusion is not altered by recent Supreme Court decisions extending substantial First Amendment protection to commercial advertising. Virginia State Bd. of Pharmacy v. Virginia Citizens Consumer Council, Inc., 44 U.S.L.W. 4686 (U.S. May 26, 1976) (invalidating state law that prohibited advertising of drug prices by pharmacists); Bigelow v. Virginia, 421 U.S. 809,825 n.10, 829 (1975) (Court reversed conviction for advertising out-of-state abortion referral service, but stated that its holding was not inconsistent with the result in Bob Lawrence, supra); Pittsburgh Press Co. v. Human Relations Comm., 413 U.S. 376, 389 (1973) (dictum that commercial advertisements for legal transactions might receive some First Amendment protection). As opposed to advertising which proposes a commercial transaction, the speech regulated by $\$ 3604$ (b) is a part of the transaction itself. Moreover, $\$ 3604(\mathrm{~b})$ does not limit what the broker can tell the buyer; it merely requires the broker to say the same thing to all similarly situated buyers.

48. While testers may be unable to establish a cause of action under $\$ 3604(\mathrm{a})$, see note 27 supra, they should have no problem under $\S 3604(\mathrm{~b})$ if they are treated differently by a broker on the basis of race.

Testers are important in fair housing litigation because bona fide buyers may decide not to sue. By the time a suit could be resolved, a buyer is likely to have found a home elsewhere. See United States v. Pelzer Realty Co., 484 F.2d 438, 441 (5th Cir. 1973), in which the defendant real estate agent told two black buyers that they could probably force a sale by bringing a suit but that "he would tie the case up in court for so long they would no longer want the house."

The value of testers as witnesses has been recognized by the courts. See United States v. Youritan Constr. Co., 370 F. Supp. 643, 647 n.3, 650 (N.D. Cal. 1973), modified on other. grounds, 509 F.2d 623 (9th Cir. 1974). In United States v. Wisconsin, 395 F. Supp. 732, 734 (W.D. Wis. 1975), the court held that a Wisconsin statute prohibiting the use of testers to gather evidence was unconstitutional under the supremacy clause as an "obstacle to the accomplishment of the principal objective of Congress in passing the Fair Housing Act."

49. Since Title VIII was first introduced on the floor of the Senate (as an amendment to H.R. 2516, 90th Cong., 2d Sess. (1968)), 114 CoNG. REc. 2270 (1968), there are no committee reports dealing with the statute. Reliance must therefore be placed on hearings and debate. For a general discussion of the legislative history, see Dubofsky, Fair Housing: A Legislative History and a Perspective, 8 WASHBURN L.J. 149 (1969).

50. See, e.g., Mayers v. Ridley, 465 F.2d 630, 652-53 (D.C. Cir. 1972) (Wilkey, J., con- 
Title VIII's stated goal of providing, "within Constitutional limitations, fair housing throughout the United States." 51

The basic purpose behind Title VIII was to encourage the dispersal of the urban ghettos that had experienced rioting and disorder ${ }^{52}$ in the summers of 1965 through 1968. To achieve this purpose Congress sought to put an end to discriminatory practices that tended to exclude blacks from white suburbs. ${ }^{53}$ Proponents of the fair housing legislation sought to attain three specific goals by ending racial discrimination in housing: preventing the humiliation inflicted by unequal treatment based on race, ensuring freedom of choice in housing, and promoting residential integration..$^{4}$ Federal courts enforcing Title VIII have sought to effectuate these purposes. ${ }^{55}$

curring); United States v. Realty Dev. Corp., 374 F. Supp. 776, 781-82 (N.D. Miss. 1972). Since the statute creates only civil penalties for violations, the strict construction generally afforded criminal statutes is not appropriate.

51. 42 U.S.C. $\$ 3601$ (Supp. IV 1974).

52. See National Advisory Commission on Civil Disorders, supra note 1, at 19.61.

53. Senator Mondale summarized the purpose of Title VIII when he introduced his fair housing bill, amendment 524 to H.R. 2516, 90th Cong., 2d Sess. (1968), which became Title VIII of the Civil Rights Act of 1968: "[F] air housing legislation is a basic keystone to any solution of our present urban crisis. . . Declining tax base, poor sanitation, loss of jobs, inadequate educational opportunity, and urban squalor will persist as long as discrimination forces millions to live in the rotting cores of central cities." 114 Cong Rec. 2274 (1968). This statement echoed the words of the proponents of the fair housing title of the 1966 civil rights bill, H.R. 14765, Title IV, 89th Cong., 2d Sess. (1966). See, e.g., 112 Conc. Rrc. 21857 (1966) (Sen. Hart). The 1966 fair housing bill, which died in a Senate filibuster, was quite similar to the subsequently enacted Title VIII. For a history of the earlier bill, see 112 CoNG. REc. 21854-55 (1966).

While the supporters of the 1968 legislation understood that only a small number of ghetto dwellers would be able to afford property in suburban areas, they believed that the fair housing title was important as an expression of the nation's concern for the well-being of its black minority. Sec, e.g., Hearings on S. 135s, supra note 13, at 2 (Sen. Mondale). Compare the minority views of Representative Whitener on the 1966 legislation, asserting that federal fair housing laws would not solve the problems of the ghetto and would only raise false hopes in American minorities. H.R. REP. 1678, 89th Cong., 2d Sess. 59 (1966).

54. See 114 Cong. Rec. 5643 (1968) (Sen. Mondale's statement that Title VIII "removes the opportunity to insult and discriminate against a fellow American because of his color"); id. at 3426 (Sen. Mansfield's statement that Title VIII would give every American "the opportunity to freely choose the house which he desires"); id. at 2283, 2525 (references to the goal of integration by Sen. Brooke).

55. Prevention of dignitary harm caused by housing discrimination was implicitly acknowledged as one rationale for Title VIII when its constitutionality was upheld as 2 "valid exercise of congressional power under the Thirteenth Amendment to eliminate badges and incidents of slavery." United States v. Hunter, 459 F.2d 205, 214 (4th Cir. 1972), cert. denied, 409 U.S. 934 (1972); accord, United States v. Youritan Constr. Co., 370 F. Supp. 643, 648 (N.D. Cal. 1973), modified on other grounds, 509 F.2d 623 (9th Cir. 1975). Another way in which courts have recognized this statutory purpose is the award of damages in Title VIII suits to compensate plaintiffs for "humiliation" caused by defendants' discriminatory conduct. See, e.g., Jeanty v. McKey \& Poague, Inc., 496 F.2d 1119, 1121 (7th Cir. 1974).

Courts have also recognized Title VIII's goals of freedom of choice, Zuch v. Hussey, 394 F. Supp. 1028, 1047 (E.D. Mich. 1975), and integration, Trafficante v. Metropolitan Life Ins. Co., 409 U.S. 205 (1972). In Trafficante, residents of an apartment complex 
Racial steering frustrates the achievement of these statutory purposes. When a broker steers, his discriminatory practices insult the dignity of black buyers and residents of black neighborhoods. ${ }^{56}$ Steering also abridges freedom of choice, because the broker excludes from the buyer's consideration a particular class of houses that meets the buyer's specifications. The practice helps to maintain all-white neighborhoods and encourages the resegregation of interracial areas by preventing buyers from seeing homes that they would have purchased had they been given the opportunity. ${ }^{57}$ Moreover, the local broker often enjoys a position of influence over a buyer new to the community, and his suggestion as to where the buyer should live can shape the buyer's preferences. ${ }^{58}$ Hence, the broker's assumption that

brought suit against the owner of the complex on the ground that his discriminatory policies excluded blacks from renting. Citing Senator Mondale's statement that "the reach of the proposed law was to replace the ghettos 'by truly integrated and balanced living patterns," "id. at 211 , the Supreme Court held that plaintiffs' allegations that they had been denied important benefits of living in an integrated apartment complex were sufficient to confer standing. Id. at 210.

56. Some residents of white neighborhoods may suffer dignitary harm from broker practices that exclude black purchasers. See Trafficante v. Metropolitan Life Ins. Co., 409 U.S. 205, 208 (1972), discussed in note 55 supra.

57. The view that some buyers, if not steered, would purchase homes in areas composed predominantly of persons of a different race is supported by recent sociological studies that indicate that factors such as "the quality and convenience of housing and neighborhood services take precedence over racial prejudice in housing decisions." Segregation in Residential Areas: Papers on Racial and Sociofconomic Factors in Choice of Housing 19 (A. Hawley \& V. Rock eds., 1973).

While it might be argued that the statute should be interpreted to permit brokers to steer in order to foster integration (for example, by allowing brokers to match black buyers with white neighborhoods), the argument must be rejected. To permit steering which fosters integration would require overriding the language of the statute, which contains no exemption for activities that promote integration. Such an interpretation would also conflict with the statutory goal of freedom of choice, because steering in any form limits the buyer's range of choices. Finally, steering which appears to promote integration could serve as a cloak for blockbusting. See p. 812 supra. Brokers who are attempting to change the racial composition of an area from predominantly white to black would be able to claim that they had steered black families into the area for purposes of integration.

The Second Circuit's decision in Otero v. New York Hous. Auth., 484 F.2d 1122 (2d Cir. 1973), does not mandate a different conclusion. In Otero, plaintiffs claimed that the policy of the New York Housing Authority to ensure racial balance in a housing project violated $\$ 3604$ and the Authority's own eligibility regulation. The court held that the Authority had an affirmative duty to promote integration that overrode its regulation and $\$ 3604$. This duty to integrate was based on 42 U.S.C. $\S 3608(d)(5)$ (1970), which requires that federally-assisted housing programs be administered "in a manner affirmatively to further the policies" of Title VIII. The statute imposes no such duty on real estate brokers. Moreover, the court recognized that use of a "benign quota" could be justified only in situations where a colorblind standard "would almost surely lead to cventual destruction of .. racial integration ..." 484 F.2d at 1136. As this Note argues, the imposition of a colorblind standard on the broker would further, rather than hinder, integration.

58. See Barresi, supra note 6 , at 59 . 
buyers prefer to live with members of their own race may become a self-fulfilling prophecy.

\section{Costs to the Broker}

Liability for racial steering will alter substantially the ordinary business practices of the broker and may inflict significant costs on his operations. To comply with Title VIII, the broker would not be able to limit the customer's choice of housing to neighborhoods with a particular racial composition. Thus he might have to show homes in several different neighborhoods. However, this cost may not be substantial, because the broker need not show more homes than is his custom. Compliance with Title VIII will also prevent the broker from excluding black buyers from white areas. Since residents of white areas may prefer to list their homes with brokers who will steer black buyers away from their neighborhoods, brokers who comply with the law are likely to be at a competitive disadvantage relative to brokers who do not comply. Vigorous enforcement of the statute ${ }^{50}$ could prevent any disadvantage to law-abiding brokers, but might lead sellers who wish to discriminate to do without brokerage services altogether. However, sellers as well as brokers are prohibited from discriminating in the sale of housing; ${ }^{60}$ therefore, the incentive to avoid brokered transactions would exist primarily in those situations where a home owner believes he can locate an "acceptable" buyer without having to refuse to sell to others on the basis of race.

There will also be enforcement costs to the broker. If found liable under Title VIII, the broker may be subject to an injunction, compensatory damages, attorney's fees, and punitive damages up to $\$ 1,000 .{ }^{81}$ Even if the broker is not found to have violated the statute, the test-

59. The United States Commission on Civil Rights has been particularly critical of Title VIII enforcement by HUD, but has noted that the Justice Department has used its limited resources efficiently. See Equal OpPortunity in Housing, supra note 2, at 174-75; II United States Commission on Civil Rights, Federal Civil. Rights Enforcement Effort-1974, at 30-47, 329 -33 (1974); United States Commission on Civil Rights, Federal Civil Rights Enforcement Effort 445-46, 493 (1970). However, as the Supreme Court noted in Trafficante v. Metropolitan Life Ins. Co., 409 U.S. 205, 209 (1972), "com. plaints by private persons are the primary method of obtaining compliance with the Act."

60. Although 42 U.S.C. $\$ 3603(\mathrm{~b})(1)$ (1970) exempts from the coverage of Title VIII certain sales by owners of single-family dwellings (such as those made without the aid of a broker and without violating $\$ 3604$ (c)'s prohibition of discriminatory advertising), homeowners who discriminate in the sale of their homes would be liable under 42 U.S.C. § 1982 (1970). See Jones v. Alfred H. Mayer Co., 392 U.S. 409 (1968); note 23 sitpra.

61. 42 U.S.C. $\$ 3612$ (c) (Supp. IV 1974). In suits brought by the Attorney General of the United States, relief is limited to an injunction. Id. $\$ 3613$ (1970). 
ing procedures themselves may inflict significant costs. Trafficante $v$. Metropolitan Life Insurance $\mathrm{Co}^{62}$ and its progeny have broadened the scope of standing under Title VIII, ${ }^{63}$ and it seems likely that "testing" activities of local fair housing groups will increase. Therefore brokers may have to devote a significant amount of time to buyers who have no interest in purchasing a home. However, this cost should be incurred only as long as brokers continue to discriminate. Burdens on the broker may also be mitigated to the extent that he is able to pass on increased costs (through higher commission rates) to sellers and, ultimately, to buyers.

Insofar as liability for racial steering inflicts costs on brokers, it must be assumed that Congress determined that any such burdens are justified by the benefits of eliminating housing discrimination. ${ }^{64}$ While preventing racial steering may not stop individual buyers from making housing choices based on race, it will help remove the real estate industry from its longstanding role in establishing and maintaining segregated living patterns. This is no more than what Congress in 1968 attempted to do.

62. 409 U.S. 205 (1972) (white tenants granted standing to challenge landlord's rental practices that excluded blacks).

63. See Heights Community Congress v. Rosenblatt Realty, Inc., P.H EQ. OPP. Hous. II 13,702 (N.D. Ohio 1975) (standing for fair housing organization alleging steering); Village of Park Forest v. Fairfax Realty, P-H EQ. OPp. Hous. \ 13,699 (N.D. III. 1975) (standing for municipal corporations, fair housing organizations, and residents of community alleging steering). But see TOPIC v. Circle Realty Co., No. 74-2147 (9th Cir. Mar. 23, 1976), aff'g in part and rev'g in part, 377 F. Supp. 111 (C.D. Cal. 1974). In TOPIC a fair housing group sought to enjoin the steering practices of defendant brokers. The plaintiffs sued under 42 U.S.C. $\$ 3612$ (a) (1970), alleging injuries similar to those alleged under $\$ 3610$ by the plaintiffs held to have standing under Trafficante; they claimed that they had been deprived of the benefits of living in an interracial community and had suffered embarrassment and cconomic loss from being stigmatized as residents of a white ghetto. TOPIC, supra, slip op. at 2. The Ninth Circuit denied standing, holding that a suit under $\$ 3612$, as opposed to $\$ 3610$, was available only to direct victims of discrimination: the section "does not authorize lawsuits to vindicate the rights of third parties." Id. at 3. The Ninth Circuit's decision in TOPIC hinders direct access to the courts by fair housing groups. However, such groups may still file a complaint under $\$ 3610$ with the Secretary of HUD; if the Secretary is unable to obtain voluntary compliance, they may bring an action in a federal court. Moreover, individual testers who are members of fair housing groups could sue under $\$ 3612$. See note 48 supra.

64. One commentator has observed that, rather than characterizing the costs of antidiscrimination laws as insubstantial, "it seems more realistic to recognize [these costs] and to assume that the justification for incurring these costs consists of the nonquantifiable value attached to the aims of the law." Fiss, $A$ Theory of Fair Employment Laws, 38 U. CHI. L. REv. 235, 254-55 (1971). 